\title{
ОСОБЛИВОСТІ ЗМІСТУ НАВЧАЛЬНОЇ ПРОГРАМИ «АНГЛІЙСЬКА МОВА ТА ЛІТЕРАТУРА» В ГОНКОНЗЬКОМУ УНІВЕРСИТЕТІ (КНР)
}

Смолярчук О. Ф. Особливості змісту навчальної програми «Англійська мова та література» в Гонконзькому університеті (КНР).

У статті розглянуто питання змісту навчальної програми та дисциплін для підготовки майбутніх філологів-бакалаврів на факультеті англійської мови в Гонконзькому університеті (КНР). Представлено вибір спеціальностей, вимоги до вступу та першого року навчання, перелік предметів 3 ознайомлювальних та поглиблених курсів для спеціальності «Англійська мова та література» 3 розподілом кредитів на кожний предмет, а також розглянуто перелік предметів і зазначено кількість кредитів 3 курсів для написання дипломної роботи. Запропоновано використання досвіду професійної підготовки філологів-бакалаврів англійської мови в Гонконзькому університеті (КНР) з метою вдосконалення підготовки таких фахівців у вищих навчальних закладах України.

Ключові слова: філолог, англійська мова та література, мова і комунікація, спеціальність, навчальна програма, кредит, ознайомлювальні курси, поглиблені курси.

Смолярчук О. Ф. Особенности содержания учебной программы «Английский язык и литература» в Гонконгском университете (КНР).

В статье рассмотрены учебная программа и курс дисциплин для подготовки будущих филологов-бакалавров на факультете английского языка в Гонконгском университете (КНР). Представлены выбор специальностей, требования к поступлению и первому году обучения, перечень предметов из ознакомительных и углубленных курсов для специальности «Английский язык и литература» с распределением кредитов на каждый предмет, а также рассмотрен перечень предметов и указано количество кредитов по курсам для написания дипломной работы. Предложено использование опыта профессиональной подготовки филологовбакалавров английского языка в Гонконгском университете (КНР) с целью совершенствования подготовки таких специалистов в высших учебных заведениях Украины.

Ключевые слова: филолог, английский язык и литература, язык и коммуникация, специальность, учебная программа, кредит, ознакомительные курсы, углубленные курсы.

Smolartchuk O. F. Features of the curriculum «English Language and Literature» at Hong Kong University (China).

The article reviews the 3-year syllabus for philologists of educational qualification of «Bachelor» in the 2013-2014 academic year and course of subjects offered for study at the School of English at the University of Hong Kong (PRC). The article states that School of English at the University of Hong Kong offers courses and conducts research of literature and cultural studies, linguistics of English language and communication. It is also stated that School of English contributes to the teaching a program of double degree «Bachelor of Arts and Bachelor of Education (English)»- «BA\&BEd in Language Education (English)», as well as the program of joint degree «Bachelor (Literary Studies) and Bachelor of Law»«BA (Literary Studies) \& LLB».

The article describes a choice of specialties at the School of English, in particular, it is 
noted that School of English proposes to study two specialties: - «English language and literature» («English Studies» (ES)); - «Language and communication» («Language and Communication» (L\&C)). Each student can choose one of them as a specialty (major) and one of them as an additional course (minor).

The article describes also the admission requirements to the School of English. Admission is made strictly on the basis of academic achievement, including the minimum level for the test in English - «5» in the Hong Kong diploma of secondary education (HKDSE) or grade «C» for the exam on defining the level of English - Use of English ASlevel exam, or its equivalents.

The article notes the first year prerequisites, a list of subjects from the introductory courses and advanced courses for the «English Studies» (ES) specialty with the amount of credits for each subject; also it is presented a list of capstone courses with a number of credits.

It is suggested to use the experience of professional training the philologists of Bachelor Degree at the English School at the University of Hong Kong (PRC) with the aim to improve the training of such specialists in higher educational institutions of Ukraine.

Key words: philologist, English Language and Literature, Language and Communication, specialty, syllabus, credit, introductory courses, advanced courses.

Знання англійської мови в нинішній час віграє все більш важливу роль в адаптації кожної людини до сучасних світових умов і надає величезні переваги майже у всіх сферах життя тим людям, які їі вивчили як іноземну. Переоцінити значення англійської мови, без усякого сумніву, дуже складно. Англійською мовою говорять в 51 країні світу. Близько 410 млн. людей є носіями англійської мови і вважають іï рідною, а близько 1 млрд.- розмовляють нею. Тому англійська мова заслужено вважається міжнародною мовою спілкування, а багато лінгвістів, спираючись на існуючі тенденції, приходять до висновку, що менше ніж через сто років мовний бар'єр практично перестане існувати, і люди будуть використовувати для спілкування виключно англійську мову [1].

У Китаї знання іноземних мов, в основному англійської, зростає в останні десятиліття 3 безпрецедентною швидкістю і масштабом. За даними недавнього опитування, для усіх, хто навчається (від учнів початкової школи до докторантів вищих навчальних закладів), курс іноземної мови $є$ обов'язковим; а англійська мова $є$ обов'язковою для приблизно $90 \%$ цих студентів. Кількість учнів початкових i середніх шкіл, що вивчають англійську мову як обов'язковий курс, досягла в цілому більше двохсот мільйонів. Якщо врахувати не тільки студентів, а також їхніх батьків, тоді стає очевидним, що вивчення англійської мови як іноземної впливає на життя майже одного мільярду китайців [3].

Mema cmammi- розглянути особливості змісту навчальної програми «Англійська мова та література» в Гонконзькому університеті (Китайська Народна Республіка).

Питанням професійної підготовки філологів англійської мови присвячені праці таких зарубіжних науковців: Ань Ченг (An Cheng), Цюїнг Ван (Qiuying Wang) історичні та соціальні аспекти викладання англійської мови у вищій школі в Китаї; Сяоя Цинь (Xiaoya Qin) - порівняння методів викладання англійської мови в китайських та австралійських університетах; Чжан Сяоцин (Zhang Xiaoqing), Хольгер Даун (Holger Daun) - реформа у викладанні англійської мови в китайських університетах у контексті глобалізації; Цян Ван (Qiang Wang) - зміни в національній навчальній програмі та їх вплив на викладання англійської мови в Китайській 
Народній Республіці; Пань Хен (Pan Heng) - комунікативний підхід у викладанні англійської мови в університетах Китаю; Вень Цюфанг (Wen Qiufang) - викладання англійської мови як міжнародної на материковому Китаї.

Однак, суттєвий інтерес викликає змістове наповнення програм професійної підготовки філологів англійської мови освітньо-кваліфікаційного рівня «Бакалавр»у китайських університетах.

Для детального уявлення щодо змісту підготовки філологів англійської мови в Китаї розглянемо правила прийому, 3-річну навчальну програму для філологів освітньо-кваліфікаційного рівня «Бакалавр» у 2013-2014 навчальному році та курс дисциплін, які пропонуються для вивчення на факультеті англійської мови в Гонконзькому університеті. Факультет англійської мови пропонує навчання i проводить дослідження літературних і культурних студій, лінгвістики англійської мови та комунікації. Факультет також робить свій внесок у викладання програми подвійного ступеню «Бакалавр 3 гуманітарних наук та бакалавр 3 педагогіки (англійська мова)»- «BA\&BEd in Language Education (English)», а також програми спільного ступеню «Бакалавр (літературознавство) та бакалавр права» - «ВА (Literary Studies) \& LLB».

Факультет пропонує для вивчення дві спеціальності:

- «Англійська мова та література» («English Studies» (ES));

- «Мова і комунікація» («Language and Communication» (L\&C)).

Кожен студент може обрати одну 3 них як спеціальність (major) та одну як додатковий курс (minor).

Прийом на факультет здійснюється виключно на основі академічної успішності, 3 ураххуванням мінімального рівня за екзамен 3 англійської мови - «5» в Гонконзькому дипломі про середню освіту (HKDSE), або оцінку «С» за екзамен на рівень знання англійської мови - Use of English AS-level exam, чи його еквіваленти.

Студенти, які мають намір обрати курс як спеціальність (major) або як додатковий курс (minor) на факультеті, повинні здати принаймні один ознайомлювальний курс зі списку «А» в перший рік. Курс як спеціальність (major) передбачає п'ять ознайомлювальних курсів - «introductory courses» (у тому числі необхідні предмети першого року навчання) і вісім поглиблених курсів - «advanced courses» (у тому числі дипломна робота - «сарstone course»). Курс як додатковий предмет (minor) включає в себе три ознайомлювальні курси - «introductory courses» (у тому числі обов'язкові предмети першого року навчання) і три поглиблені курси «advanced courses». Студенти, які бажають записатися на поглиблені курси («advanced courses»), повинні завершити три ознайомлювальні курси («introductory courses»), серед них, принаймні, один курс зі списку «А» і один курс зі списку «В».

Вибір предметів і курсів затверджується факультетом. Студенти повинні переглянути веб-сторінку факультету щодо актуальних запропонованих курсів i мають повідомити, що їх вибір курсів відповідає всім необхідним умовам, закладених факультетом. Студентам, які вивчають курс «Англійська мова i комунікація»«English Studies and Language and Communication» як спеціальність, надається пріоритет під час вступу на поглиблені курси - «advanced courses» за їх відповідною спеціалізацією.

Предметом курсу «Англійська мова та література» («English Studies» (ES)) $\epsilon$ вивчення та критичний аналіз англійської мови в іiі численних застосуваннях в соціальному та історичному контекстах з різних точок зору, включаючи лінгвістику, літературознавство, літературну творчість, а також критику і теорію культури. Цей курс має міжкультурне спрямування, визнаючи англійську мову як мову 
міжнародного спілкування та світової літератури.

Курс «Англійська мова та література» як спеціальність складається 330 кредитів ознайомлювальних курсів - «introductory courses» (включаючи обов'язкові предмети) i 48 кредитів поглиблених курсів - «advanced courses» (у тому числі дипломна робота - «сарstone courses»). Курс «Англійська мова та література» пропонує студентам як грунтовну підготовку, так і широкий спектр варіантів у різних конгрегаціях.

В ознайомлювальних курсах («introductory courses») особливого значення надається практиці критичного читання, аналізу і письму, а також розвитку історичних і теоретичних знань.

У поглиблених курсах («advanced courses») увага зосереджується на англійській мові та літературі як репрезентаціях культури та суспільства в різних історичних контекстах, на її значенні в різних дискурсивних контекстах, жанрах і засобах масової інформації, на місці англійської мови у її зв'язку з історичними періодами колонізації і глобалізації з особливим посиланням на Гонконг.

Уважаємо важливим, що вибір курсів з написання дипломної роботи («саpstone courses»), в тому числі науково-дослідних семінарів, стажування та підсумкових колоквіумів на останньому курсі (senior colloquia), надають студентам можливість інтегрувати і спрямувати їх навчання на спеціальність, ураховуючи їхні можливості після закінчення навчання.

Варто взяти до уваги, що курс «Англійська мова та література» об'єднує різноманітні методи викладання і навчання, в тому числі лекції, семінари, навчальні консультації в невеликих групах, семінари-воркшопи та навчання в режимі он-лайн. Вони оцінюються, в основному, за курсовою роботою, включаючи усні доповіді, аудиторні тести і вікторини, есе і дослідні проекти та портфоліо. Ці методи розроблені, щоб сформувати у студентів навички точного та історично сприйнятливого аналізу, критичного читання i мислення, ясного і послідовного аргументування у вміннях говоріння та письма.

Зазначимо, що студентам пропонується обговорити їхні навчальні плани і вибір навчальних предметів 3 їх академічними консультантами або будь-яким викладачем на факультеті англійської мови.

Щодо необхідних умов для допуску на перший рік навчання, то студенти, які бажають взяти курс «Англійська мова та література»- English Studies (ES) як спеціальність або як додатковий предмет, повинні здати принаймні один ознайомлювальний курс 3 англійської мови («introductory ENGL course») зі списку «A»- «Історичні і теоретичні основи» (6 кредитів) протягом першого року. Вступ на всі ознайомлювальні курси («introductory courses») здійснюється на основі академічної успішності, що включає мінімальний рівень за екзамен 3 англійської мови - «5» в Гонконзькому дипломі про середню освіту (HKDSE) або оцінку «С» за екзамен «the Use of English AS-level exam» на рівень знання англійської мови чи його еквіваленти.

Студенти, які обрали курс «Англійська мова та література» (English Studies) як спеціальність, повинні здати 30 кредитів ознайомлювальних предметів (включаючи ті предмети, які потрібно здати протягом першого року), які, як правило, можна вибирати для вивчення протягом перших двох років навчання. Вони повинні включати в себе щонайменше 12 кредитів зі списку «А»- «Історичні і теоретичні основи» і щонайменше 12 кредитів зі списку «В»-«Критичне читання, аналіз і письмо».

Студенти, які обрали курс «Англійська мова та література» (English Studies) як 
додатковий курс, повинні здати 18 кредитів ознайомлювальних предметів, де має бути щонайменше 6 кредитів зі списку «А» і 6 кредитів зі списку «Б».

Вивчаючи предмети зі списку А («Іторичні і теоретичні основи»), студенти ознайомлюються 3 історією та організацією різних галузей літературної та лінгвістичної науки, здобувають загальний огляд окремих галузей і проблем, в тому числі основних теоретичних відмінностей і класифікацій та їх історичного розвитку протягом довгого часу.

До цього списку входять такі предмети: «Вступ до вивчення змісту», «Мова як соціальна дія», «Вивчення модерну: читання англійських творів початку ХХ століття», «Вступ до лінгвістики англійської мови», «Вступ до кореспонденції», «Вступ до соціолінгвістики», «Мова і гендер», «Література та імітація», «Література та культура XIX століття», «Періоди історії літератури», «Поезія в минулому і сьогоденні», «Погляд 3 нізвідки: експериментальна проза», «Теми в світовій літературі», «Розуміння оповідань», «Переконання», «Вступ до теорії літератури», «Мова, комунікація, суспільство, оточення», «Теоретична комунікація», «Вступ до прагматики». На вивчення кожного предмета відводиться по 6 кредитів.

Вивчаючи предмети зі списку В («Критичне читання, аналіз і письмо»), студенти знайомляться 3 практикою i методами критичного читання, аналізу i письма, приділяючи особливу увагу різним галузям літературного i лінгвістичного дослідження. Студенти набувають розуміння аналітичних відмінностей і термінології, вчаться ставити питання і конструювати критичні аргументи.

До цього списку належать такі предмети: «Уявні географії: мистецтво опису локації», «Адаптація: з тексту на екран», «Аналіз дискурсу», «Пробудження: вивчення жіночого письма», «Драма: комедія та оновлення», «Драматичні зміни: версії літератури Відродження», «Англійська граматика(и)», ««Висока» та «низька» література», «Міжкультурне спілкування», «Мова і забобони», «Мовні злочини», «Значення i метафора», «Практика критики», «Реалізм i репрезентація», «Переписування i реагування на письмові форми», «Сучасність і літературний модернізм», «Питання англійської мови в світі», «Вступ до англійської поезії ХХ століття». На вивчення кожного предмету відводиться також по 6 кредитів.

Щодо поглиблених курсів («Advanced courses»), то студенти, які обрали курс «Англійська мова та література» (English Studies) як спеціальність, повинні здати 48 кредитів з предметів зі списку, який наведений нижче; він має містити 6-кредитний курс 3 написання дипломної роботи («сарstone course»), який можна обирати в останній рік навчання.

Студенти, які обрали курс «Англійська мова та література» (English Studies) як додатковий предмет, повинні здати 18 кредитів 3 предметів цього курсу. Студентам пропонується обговорювати їх навчальні плани і вибір курсів 3 їх навчальними консультантами або будь-якими викладачами на факультеті англійської мови.

Для того щоб записатися на будь-який поглиблений курс («advanced course») зі спеціальності «Англійська мова та література» (English Studies), студенти повинні здати 18 кредитів з предметів ознайомлювальних курсів (introductory courses) зі щонайменше 6 кредитами зі списку «А» та списку «В».

До цього списку входять такі предмети: «Мова в суспільстві», «Синтаксис англійської мови», «Літературна лінгвістика», «Англійський роман I», «Англійський роман II», «Теорія сучасної літератури», «Жінки, фемінізм і письмо I», «Англійська мова в світі», «Семантика і прагматика англійської мови», «Читання поезії», «Гендер і дискурс», «Подорожні нотатки», «Структури і стратегії дискурсу англійської мови», «Мова і жаргон», «Збірник лінгвістики англійської мови», «Американська готика: 
будинки 3 привидами», «Текст і образ», «Форма і зміст», «Постколоніальна література», «Ідея Китаю», «Романтизм», «Роман в сьогоденні», «Шекспір», «Жінки, фемінізм і письмо II», «Творче письмо I», «Творче письмо II», «Створення американської літератури: література як ритуал і оновлення», «Постколоніальна англійська література», «Літературні острови: англійська поезія і проза південної частини Тихого океану і Карибського басейну», «Схід: Азія в англійських творах», «Уявляючи Гонконг», «Мова, ідентичність, американці азійського походження», «Культура і суспільство», «Мова і нові медіа», «Мова в США», «Вступ до історії англійської мови і літератури», «Теорії засвоєння мови», «Фонологія і морфологія англійської мови», «Правило і література», «Англійська мова і література в Гонконзі», «Наукова фантастика i утопія», «Комедія, оновлення i міжкультурна драма», «Вікторіанці на батьківщині і за кордоном», «Мова та ідентичність в Гонконзі», «Граматика англійського речення», «Правило, зміст, інтерпретація», «Юридичний дискурс і юридична думка», «Модернізм», «Англійська мова як мова науки», «Знаки, мова i значення: інтеграційні роздуми», «Критик як художник», «Міжкультурні питання і теорії», «Теми в міжкультурних дослідженнях: галузь знань, методологія і правила», «Світова література», «Космополітичні уявлення», «Міжкультурні дискурси», «Професія драматурга в Англії в епоху раннього модернізму», «Мова і глобалізація», «Американська сучасна література», «Ідеології мови в епоху раннього модернізму», «Аналіз дискурсу», «Теорії мови і комунікації», «Мова в робочому середовищі», «Мова і ввічливість», «Мова, комунікація та засоби масової інформації», «Мова, комунікація та глобалізація», «Візуальна комунікація», «Комунікація здоров’я, «здорова комунікація». На вивчення кожного предмета відводиться по 6 кредитів.

Цікавим у порівнянні з практикою вітчизняних університетів є запровадження до програми підготовки філологів у Гонконзькому університеті курсів 3 написання дипломної роботи («Capstone courses»), які передбачають такі види навчальної діяльності: «Теми для поглибленого вивчення в англійській мові та літературі», «Дослідницький семінар 3 вивчення англійської мови і літератури», «Дослідницький семінар 3 вивчення англійського літературознавства», «Дослідницький семінар 3 вивчення лінгвістики англійської мови», «Дослідницький семінар 3 вивчення мови та суспільства», «Дослідницький семінар 3 вивчення міжкультурних досліджень 3 англійської мови», «Стажування в дослідженні англійської мови та літератури», «Головний колоквіум з англійської мови і літератури», «Розгорнуте есе 3 англійської мови і літератури». На кожен з вищезазначених курсів виділяється по 6 кредитів, крім курсу «Теми для поглибленого вивчення в англійській мові та літературі», - на нього відводиться 12 кредитів [2, с. 40-43].

Розглянувши навчальну програму (2013-2014 навчального року) для філологів освітньо-кваліфікаційного рівня «Бакалавр» та курс дисциплін, які пропонуються для вивчення на факультеті англійської мови в Гонконзькому університеті, можна зазначити, що факультет пропонує для вивчення дві спеціальності, а саме: «Англійська мова та література - English Studies (ES)», «Мова і комунікація Language and Communication (L\&C)». При цьому кожен студент може обрати одну 3 них як спеціальність (major) та одну як додатковий курс (minor), що сприяє кращому розумінню студентами суміжних предметів та заохочує їх до самостійної пошукової діяльності. Особливим досягненням факультету є викладання програми подвійного ступеню: «Бакалавр з гуманітарних наук та бакалавр 3 педагогіки (англійська мова)»«BA\&BEd in Language Education (English)», а також програми спільного ступеню: «Бакалавр (літературознавство) та бакалавр права» - «BA (Literary Studies) \& LLB», що дає можливість студентам стати фахівцями одночасно 3 двох спеціальностей. 
Варто зазначити і про умови вступу на факультет англійської мови, які є досить високими, адже прийом на факультет здійснюється виключно на основі академічної успішності, включаючи мінімальний рівень за екзамен 3 англійської мови - «5» в Гонконзькому дипломі про середню освіту (HKDSE), або оцінку «С» за екзамен на рівень знання англійської мови - Use of English AS-level exam, чи його еквіваленти.

Перспективи подальших наукових досліджень можуть бути пов'язані 3 вивченням змісту дисципліни «Англійська мова» для освітньо-кваліфікаційного рівня «Магістр» в університетах КНР та дослідження питання проведення педагогічної практики.

\section{Література}

1. Англійська мова та іiі важливість на сьогоднішній день. [Електронний pecypc].- Режим доступу: http:/www.movi.com.ua/angliyska-mova/813-angliyskamova-i-yiyi-vaglivist 2. Regulations and syllabuses (BA 3-year curriculum in the academic year 2013-2014) [Електронний ресурс] - Режим доступу: http://arts.hku.hk/ BAprogramme/2010/advising/BA \%20 RegulationsSyllabuses \%202013-14.pdf. 3. Xie Bangxiu. English in China Today (Wuhan, China) [Електронний ресурс]/ Bangxiu Xie.- Режим доступу: http://www.jesusjazzbuddhism.org/ english-in-chinatoday.html

\section{ACCORDION TRAINING IN MUSIC SCHOOLS IN SERB ACADEMICALLY POPULAR TYPE}

Устименко-Косоріч О. А. Професійна підготовка баяністів-акордеоністів в сербських музичних школах академічно-народного типу. У статті проаналізовано професійна підготовка баяністів-акордеоністів сербської школи академічно-народного типу за двома освітніми напрямами професіонал/аматор, які презентують прогресивну освітню систему, що реалізовує двоєдину біфункціональну програму - виховання компетентного фахівця суспільно-національного призначення (аматора) та потенційного виконавця «Високого мистецтва» засобами «узагальнення через жанр».

Ключові слова: професіонал, аматор, музична школа, баян-акордеон, підготовка, нація, суспільство, виконавство.

Устименко-Косорич Е. А. Профессиональная подготовка баянистоваккордеонистов в сербских музыкальных школах академически-народного типа.

В статье анализируется профессиональная подготовка баянистов-аккордеонистов сербской школы академически-народного типа по двум образовательным направлениям - профессионал / любитель, которые представляют прогрессивную образовательную систему, реализующая двуединую бифункциональных программу воспитание компетентного специалиста общественно-национального назначения (любителя) и потенциального исполнителя «Высокого искусства» средствами «обобщение через жанр».

Ключевые слова: профессионал, любитель, музыкальная школа, баян-аккордеон, подготовка, нация, общество, исполнительство.

Ustymenko-Kosorich O. A. Accordion training in music schools in Serb academically popular type.

The article analyzes the training of accordion Serbian school of academically popular 